\title{
PEMBELAJARAN ASG: \\ FORMASI OMK SEBAGAI AGEN PERUBAHAN GEREJA DAN MASYARAKAT
}

\author{
Liria Tjahaja, Yap Fu Lan \\ Prodi Pendidikan Keagamaan Katolik \\ Fakultas Pendidikan \& Bahasa \\ Unika Indonesia Atma Jaya
}

\begin{abstract}
For more than one century, Catholic social teaching (CST) has become the wealth of faith of the church. Nonetheless, CST has not been made known to lay people at the grassroots level, in particular to young people. This article contains the results of two studies on this issue. The studies were conducted in 2012 and 2015-2016 involving young Catholics who were students of Catholic schools in Jakarta and its surrounding areas. The result of the first study in 2012 showed that most young Catholics have a lack of knowledge about CST. The second study was carried out in two phases. In 2015, the first phase of study was in the form of workshop and a CSTthemed-film-and-photography competition. Forty students from eight Catholic high schools in Jakarta and Bogor participated in both the workshop and the competition. The second stage of the study was done in 2016 through focused group discussions and interviews involving young Catholics, their teachers, and the heads of their schools. The foci of this second stage study was CST learning process and its impacts to the life of young people. The processes as well as the results of these two phases of study were scrutinized. The final finding was the ideas of learning CST that functions as a formation of social-change agents. The ideas include features of process, learning content, peer group characteristics, and opportunities for interreligious, intercultural, and intergeneration education.
\end{abstract}

Keywords: Catholic social teaching, young people, social-change agents 


\section{PENDAHULUAN}

Ajaran Sosial Gereja (selanjutnya ASG) merupakan ajaran yang didasarkan pada hidup dan karya Yesus Kristus yang memiliki perhatian dan komitmen kepada kaum lemah dan miskin. ASG menjadi ajaran penting bagi Gereja karena menampilkan Gereja sebagai Sakramen Kerajaan Allah yang membawa keselamatan bagi dunia (Lumen Gentium, art. 5). Selama 126 tahun ASG telah menjadi ajaran dan tradisi Gereja Katolik, dimulai dari penerbitan pesan apostolik Rerum Novarum (1891) oleh Paus Leo XIII. Usia ASG sudah melampaui satu abad, namun isi ajaran yang menampilkan identitas Gereja sebagai komunitas sosial di tengah kehidupan masyarakat rupa-rupanya belum kuat bergaung di dalam kehidupan umat beriman Katolik sendiri.

Keadaan tersebut terlihat di dalam hasil studi yang pernah dilakukan oleh Liria Tjahaja pada tahun 2012 tentang pemahaman Orang Muda Katolik (OMK) di Keuskupan Agung Jakarta mengenai sikap dan pandangan Gereja terhadap orang miskin dan masalah-masalah kemiskinan. Hasil studi Tjahaja menunjukkan bahwa pada dasarnya orang muda mempunyai perhatian terhadap kaum miskin dan isu kemiskinan. Orang muda mampu mengenali berbagai fenomena dan faktor penyebab kemiskinan, serta memahami kemiskinan sebagai isu yang lebih luas dari masalah kekurangan pangan, sandang, papan, dan penghasilan. Namun, sebagian besar OMK, bahkan yang bersekolah di sekolah-sekolah Katolik, tidak memiliki pengetahuan tentang keberpihakan Gereja kepada kaum miskin dan tentang ASG. Di dalam studi itu, Tjahaja menemukan juga fakta kelemahan proses pendidikan iman pada umumnya yang diperoleh OMK, sehingga pembenahan isi, metode, dan proses pendidikan iman menjadi kebutuhan yang mendesak. (Tjahaja, 2012: 30-74.)

Sebagai lembaga pendidikan yang membina para calon pendidik keagamaan Katolik, Program Studi Pendidikan Keagamaan Katolik, Fakultas Pendidikan dan Bahasa di Unika Atma Jaya (selanjutnya Prodi Pendikkat) melihat pentingnya memperkenalkan ASG kepada umat beriman, khususnya OMK, serta menumbuhkembangkan nilai-nilai ASG di dalam diri mereka. Tantangan bagi Prodi ialah memperkenalkan ASG kepada OMK dengan cara-cara yang menarik dan relevan bagi orang muda sekaligus dapat menarik OMK untuk ikut berperan menghidupkan ASG di dalam kehidupan sehari-hari.

Pertanyaan tersebut menjadi pijakan penulis untuk menguraikan makalah ini. Pada bagian pertama, penulis memaparkan secara singkat refleksi penulis mengenai ASG, khususnya dalam konteks kehidupan dan pembinaan OMK. Di bagian kedua, penulis memberikan gambaran mengenai proses dan hasil penelitian yang dilakukan oleh Prodi Pendikkat, di mana penulis terlibat. Penelitian itu terdiri atas dua tahap. Tahap pertama dilaksanakan dalam bentuk lokakarya dan kompetisi mengenai ASG bagi OMK (tahun 2015). OMK yang 
menjadi subjek kegiatan ini adalah siswa-siswa Sekolah Menengah Katolik di Jakarta dan sekitarnya. Proses lokakarya dan kompetisi tersebut diharapkan menjadi proses pembelajaran bagi OMK untuk mengenal dan menanam nilai-nilai dasar ASG di dalam diri OMK sehingga mampu berperan sebagai agen transformasi di dalam komunitas Gereja dan masyarakat. Pada tahap kedua (tahun 2016), Prodi melakukan diskusi kelompok terarah dan wawancara dengan siswa, guru, dan pimpinan sekolah-sekolah yang berpartisipasi di dalam kegiatan lokakarya dan kompetisi. Hasil akhir dari kedua tahap penelitian tersebut, berisi gagasan-gagasan mengenai pembelajaran ASG bagi OMK. yang oleh penulis diuraikan di bagian ketiga dari makalah ini dan sekaligus menjadi penutup seluruh makalah.

\section{PEMBAHASAN}

\subsection{ASG Dihadapkan pada Tantangan Situasi Orang Muda Masa Kini}

Bagi Gereja Katolik, ASG yang paling dasar terdapat di dalam Kitab Suci, khususnya di dalam Injil yang memuat ajaran-ajaran Yesus Kristus dalam rangka mewujudkan Kerajaan Allah di dalam kehidupan manusia. Ajaran-ajaran itu terus menerus menjadi bahan berbagai refleksi Gereja dalam menanggapi aneka realitas hidup masyarakat zamannya. ASG tidak terpisahkan dari pemahaman mengenai martabat dan kehidupan manusia, yang bersumber dari Allah. Setiap pribadi manusia diciptakan dalam gambar Allah, dimerdekakan oleh Yesus Kristus, dan oleh sebab itu patut dihargai setinggi-tingginya. Kesadaran ini semakin meneguhkan bahwa komitmen pada misi sosial Gereja yang dirumuskan di dalam ASG harus berakar di dalam kehidupan spiritualitas umat beriman. ASG tidak dapat dipelajari sekadar sebagai teori, melainkan sampai ke penghayatan, mewujud di dalam sikap dan tindakan hidup sehari-hari. Nilai-nilai penghayatan seperti ini juga dibahas dalam rangkuman Sidang Agung Gereja Katolik Indonesia (SAGKI 2005), yang menyuarakan soal budaya atau habitus baru, yang menyentuh dan melibatkan pola pikir, pola rasa dan sikap, serta pola tindak orangorang beriman yang dibentuk terus menerus dengan semangat pertobatan.

Secara umum, orang muda di era zaman ini, dipandang sebagai the digital native atau the Net-generation, generasi digital, generasi internet. Istilah ini menandakan bahwa mereka adalah generasi yang lahir dalam masa perkembangan pesat teknologi komunikasi berbasis komputer dan internet. Orang muda fasih berbahasa teknologi, khususnya teknologi digital, dan memiliki citra atau gambar diri yang berbeda dari generasi sebelumnya. Gustavo S. Mesch menggambarkan generasi Net dengan dua sisi yang kontras. Di satu sisi, generasi Net adalah pencipta a bedroom culture, budaya kamar tidur. Ruang gerak mereka semakin privat dan tak terjangkau oleh orangtua mereka sekalipun. (Mesch, 2009: 51), Gambaran tersebut semakin menguatkan ciri perilaku orang muda yang dikenal 
secara umum oleh masyarakat. Orang muda diyakini sebagai kelompok yang paling rentan terhadap pengaruh negatif perkembangan zaman, termasuk teknologi digital; penganut hedonisme, materialisme, konsumerisme, dan individualisme; berorientasi kepada dirinya sendiri, dan oleh sebab itu, bersikap cuek, acuh tak acuh terhadap situasi sekitarnya.

Di sisi lain, menurut Mesch, orang muda sebagai generasi Net memiliki ekspresi berbagai nilai, sikap, dan perilaku yang juga berbeda dari generasi sebelumnya. Orang muda-pun memiliki preferensi belajar dan preferensi sosial tersendiri. Berdasarkan talenta teknologi yang dimilikinya, orang muda menjadi pekerja-pekerja yang optimis dan berorientasi pada tim; aktif bereksperimen; dan tentu saja sangat mengandalkan teknologi dalam mencari informasi dan berkomunikasi. Orang muda juga berhasrat tinggi untuk terampil mengembangkan berbagai presentasi multimedia yang kreatif dan menjadi produsen multi-media (Mesch, 2009: 51-53). Kemampuan orang muda yang secara kritis menanggapi fenomena teknologi komunikasi dan dampaknya bagi relasi antar manusia, dan bagi relasi manusia dengan Allah, serta kemampuan menentukan sikap dalam menggunakan media komunikasi, terungkap di dalam penelitian berjudul "Orang Muda Bicara tentang Pengaruh Komunikasi Berbasis Komputer terhadap Kehidupan Umat Beriman” (Yap, 2012: 51-56).

Ciri karakter dan potensi orang muda pada umumnya dimiliki pula oleh OMK. Pembinaan untuk generasi muda Katolik sangat dibutuhkan dan perlu diupayakan terus menerus. Hal yang harus diupayakan oleh Gereja adalah menyediakan pendidikan yang berlandaskan pada nilai-nilai Katolik. Gereja Katolik merupakan sebuah masyarakat, sekaligus bagian dari masyarakat dimana Gereja tersebut berada. Gereja mengembangkan di dalam dirinya suatu kebudayaan yang mencerminkan keyakinan imannya. Kebudayaan itu dikenal sebagai kebudayaan kasih, yang melandasi relasi antar manusia, antara manusia dan makhluk ciptaan lainnya, serta antara manusia dan Allah Penciptanya. (Cully,1995: 4-7). Kebudayaan yang dihidupi Gereja ini mencakup norma-norma yang menjadi acuan hidup anggota-anggota Gereja.

Norma objektif dari kebudayaan Gereja, yang juga menjadi norma bagi pendidikan yang dikembangkan oleh Gereja adalah: Allah yang terlibat di dalam peristiwa hidup manusia melalui pribadi dan karya Yesus Kristus, yang diungkapkan di dalam Injil dan kitab-kitab Perjanjian Baru, yang kemudian dikembangkan dan diwariskan oleh Gereja di dalam ASG. Dengan norma ini pula pendidikan informal di dalam keluarga-keluarga Katolik, pendidikan formal di sekolah-sekolah Katolik, dan pendidikan di lingkungan gerejawi lainnya diharapkan mampu mengarahkan OMK untuk bertanggung jawab menyatakan kehendak Allah; mendorong OMK turut berperan, ambil bagian di dalam perbaikan dan pengembangan kehidupan masyarakat, sesuai rencana Allah dalam 
menyelamatkan manusia beserta kehidupannya. Sayangnya, sebagaimana terlihat dalam hasil studi Tjahaja, pewarisan norma itu belum sungguh terjadi, sebab belum banyak OMK yang mengenal apalagi memahami ASG.

Lokakarya dan kompetisi mengenai ASG (2015) merupakan langkah yang diupayakan Prodi Pendikkat untuk menanggapi keadaan tersebut. Kegiatan ini bertema: "Net-Gen: Agent of Change, Generasi Net Membangun Kesadaran untuk Transformasi Sosial.” Sejumlah delapan sekolah Katolik menyambut undangan Prodi untuk terlibat di dalam kegiatan ini, yaitu: (1) SMK Strada III, Tanjung Priok, (2) SMA Ricci II, (3) SMK Asisi, (4) SMK St. Maria, Juanda, (5) SMA Tarsisius, (6) SMK Fransiskus, (7) SMK St.Theresia, dan (8) SMA Budi Mulia, Bogor. Masing-masing sekolah mengirimkan lima orang siswa dan satu orang guru pendamping. Sekolah Katolik menjadi pilihan Prodi Pendikkat sebagai rekan kerja di dalam kegiatan ini sebab sekolah Katolik adalah institusi pendidikan berbasis iman yang memiliki tanggung jawab untuk memilih dan mengembangkan kurikulum dan metodologi pengajaran dengan acuan kebudayaan dan norma-norma Gereja Katolik. (Cully, 1995: 7, 2.) Selain itu, sekolah memiliki "kedudukan di masyarakat" yang memberinya peluang untuk “mengembangkan pola-pola pemikiran masyarakat.” (Cully, 1995: 2.) Dengan kata lain, sekolah-sekolah Katolik merupakan tempat pembentukan generasi muda Gereja dan masyarakat untuk suatu transformasi sosial dan secara essensial gagasan ini-pun sejalan dengan cita-cita ASG.

\subsection{OMK Belajar ASG: Teori, Refleksi, dan Ekspresi}

Proses lokakarya berlangsung dalam dua bagian kegiatan belajar. Bagian pertama terarah pada pengenalan dasar, isi, dan berbagai dokumen ASG. Para peserta diajak untuk mempelajari dan mengkaji realitas masyarakat megapolitan dan isu-isu yang mereka hadapi: kemiskinan, keadilan, lingkungan hidup, dan media komunikasi. Kegiatan belajar pada bagian ini terdiri dari pemaparan narasumber mengenai (teori-teori) ASG dengan ruang lingkup yang terbatas pada keempat isu, yang didalami oleh para siswa melalui diskusi kelompok ; kegiatan eksposur yang dilakukan siswa di pasar, jalan raya, rumah sakit, dan pusat perbelanjaan untuk menangkap fenomena-fenomena situasi konkret kehidupan masyarakat; proses analisa dan refleksi siswa bertolak dari pengalaman mereka melihat dan menangkap fenomena-fenomena sosial di tengah masyarakat. Contoh hasil proses ini terlihat pada Gambar 1. 


\section{Gambar 1}

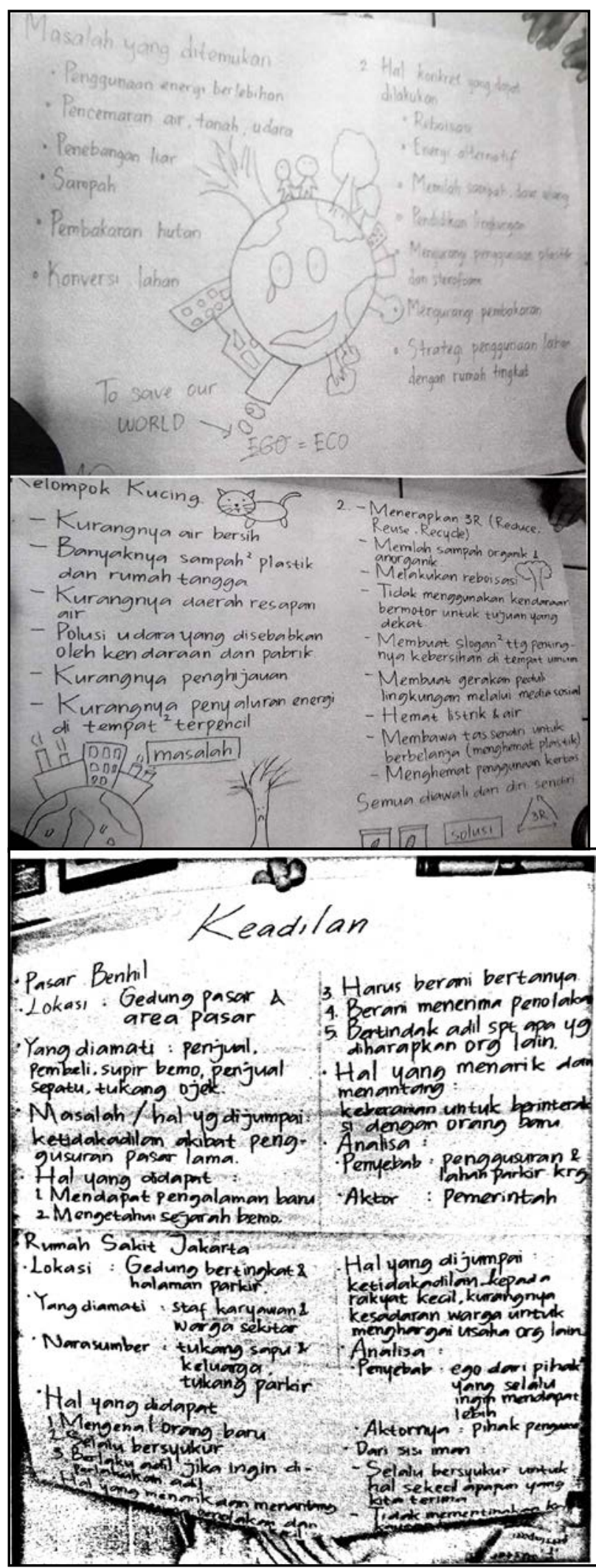

Pada akhir lokakarya, para siswa memberikan evaluasi terhadap materi ASG yang disampaikan, metode/cara penyampaian, pengaturan waktu, relasi dengan narasumber dan panitia. Evaluasi menunjukkan bahwa $92 \%$ peserta menilai materi ASG yang disampaikan baik. Terkait dengan metode pembelajarannya, $63 \%$ peserta menilai metode yang diterapkan baik, 34\% menyatakan cukup, dan 3\% menyatakan kurang. Secara umum, para siswa mengungkapkan bahwa metode yang dinilai membosankan adalah metode ceramah, saat narasumber menyampaikan materi ASG. Metode yang diminati oleh para siswa adalah metode eksposur, yang memberi kesempatan kepada para siswa untuk belajar melihat realitas sosial sehari-hari dan mengaitkannya dengan nilainilai ASG.

Selain evaluasi yang lebih bersifat teknis, para siswa juga merefleksikan proses dan pengalaman mereka. Berdasarkan proses refleksi yang dilakukan, siswa mengakui bahwa di dalam diri mereka tumbuh berbagai kesadaran untuk:

a) bersikap peka terhadap sesama, terutama saudarasaudara yang hidupnya 
tidak tercukupi,

b) peduli pada lingkungan dan kelestariannya,

c) berpikir kritis,

d) hidup lebih beriman,

e) bersyukur atas segala sesuatu yang dimiliki,

f) belajar mendengarkan,

g) mengatur waktu dalam menggunakan gadget,

h) mengamalkan ajaran Gereja dalam kehidupan sehari-hari,

i) menegakkan keadilan bagi sesama,

j) membuat perubahan yang baik, sesuai ajaran Gereja.

Bagian kedua dari proses belajar para siswa adalah pengenalan media film dan foto esai, beserta teknik-teknik pembuatannya masing-masing, bersama para narasumber. Kelima orang siswa utusan tiap sekolah membentuk dua tim kerja berdasarkan kategori kedua media tersebut. Tim media film terdiri dari tiga orang siswa, sedangkan tim foto esai terdiri dari dua orang siswa. Usai lokakarya, para siswa merancang ide yang kemudian dikembangkan sebagai skenario dan diekspresikan dalam bentuk film pendek dan foto esai. Film dan foto karya para siswa didiseminasikan ke masyarakat luas melalui media sosial Youtube dan Instagram. Apresiasi untuk kreativitas diperoleh para siswa dalam bentuk penilaian dan kritik-saran dari para juri (narasumber lokakarya), dan penilaian publik lewat simbol-simbol likes dan comments, seperti terlihat pada Gambar 2.

\section{Gambar 2}

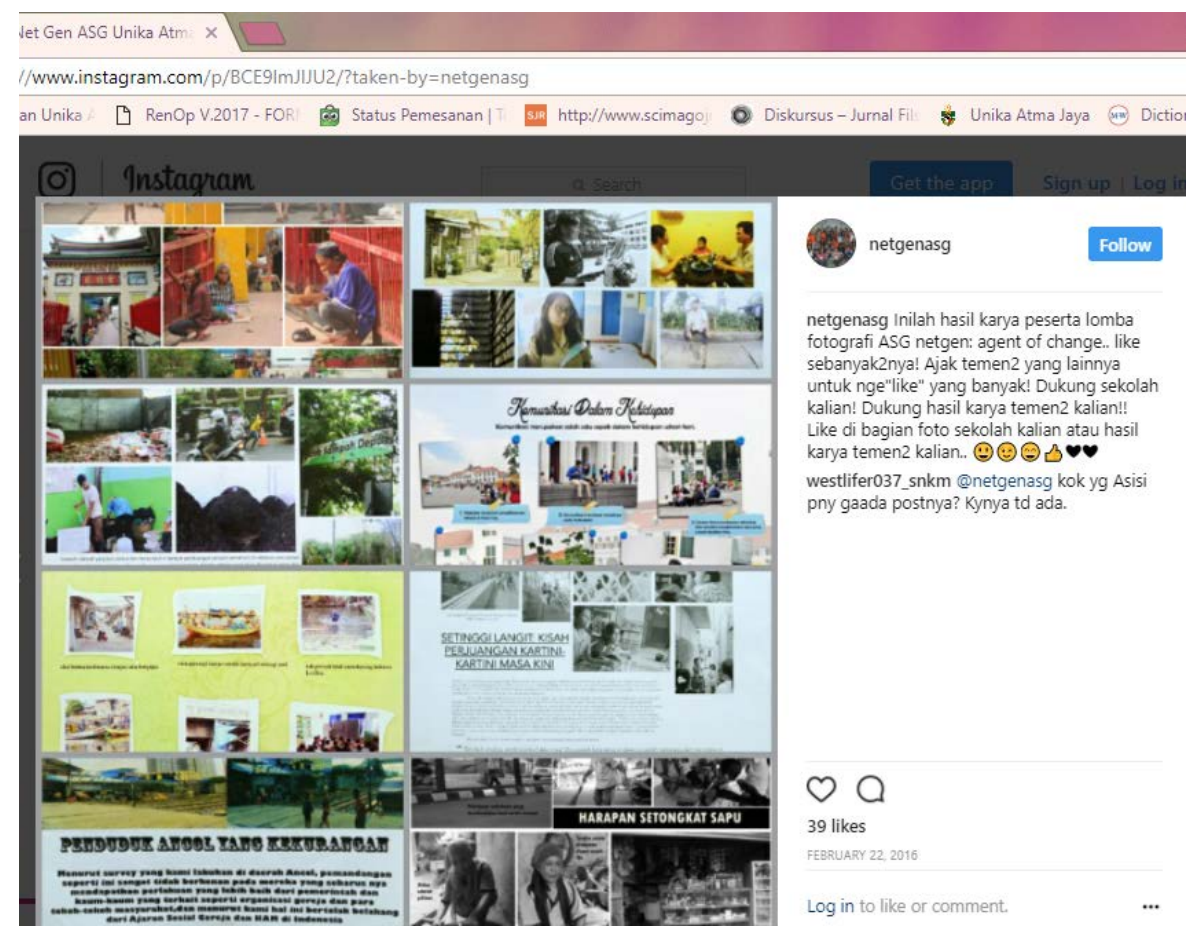


Hasil lokakarya dan kompetisi menjadi pijakan Prodi Pendikkat untuk melakukan penelitian lanjutan dalam rangka menemukan dan mengembangkan bentuk pembelajaran ASG bagi OMK. Para siswa dari sekolah-sekolah yang berpartisipasi di dalam lokakarya dan kompetisi ASG menjadi subjek penelitian. Ada enam dari delapan sekolah yang ikut serta di dalam penelitian lanjutan ini. Pertanyaan pokok penelitian adalah: Bagaimana isi, bentuk, dan proses pembelajaran ASG yang menarik dan relevan bagi orang muda Katolik di dalam konteks hidup masyarakat megapolitan di jaman ini? Pertanyaan pokok ini diuraikan dalam empat pertanyaan berikut:

1) Adakah relevansi antara topik/lingkup materi ASG dan realitas kehidupan orang muda Katolik megapolitan?

2) Bagaimana efektivitas metode pembelajaran ASG yang diterapkan di dalam lokakarya?

3) Bagaimana pengalaman terlibat di dalam pelatihan ASG mempengaruhi cara pandang siswa dan sekolah terhadap ASG dan pembelajaran ASG?

4) Bagaimana pengalaman terlibat di dalam lokakarya ASG mempengaruhi dinamika pembelajaran agama Katolik di sekolah?

Penelitian ini menggunakan pendekatan kualitatif, dengan menerapkan metode wawancara mendalam dan metode diskusi kelompok terarah. Wawancara dilakukan untuk memperoleh pandangan para kepala sekolah dan guru pendamping mengenai pembelajaran ASG. Sedangkan diskusi dilakukan bersama para siswa yang terlibat sebagai peserta lokakarya dan kompetisi ASG serta para siswa lain yang menjadi pendukung (supporter) yang hadir di dalam acara kompetisi ASG untuk memperoleh dampak yang dialami siswa setelah menjalani lokakarya dan kompetisi ASG.

Pendapat siswa mengenai kegiatan lokakarya dan kompetisi ASG, menunjukkan bahwa kegiatan tersebut memberikan wawasan pengetahuan yang bermanfaat dan membuka peluang untuk para siswa membuat jejaring komunikasi dengan teman sebaya. Para siswa juga berpendapat bahwa lokakarya menarik karena menampilkan tokoh-tokoh dalam masyarakat yang memiliki kompetensi di bidang yang diminati kaum muda, yakni cinematografi dan fotografi. Lokakarya berhasil menarik siwa untuk lebih mendalami ASG yang belum banyak dibahas di sekolah. Bagi pihak sekolah sendiri, proses pembelajaran ASG yang dilakukan menjadi sumber inspirasi dalam untuk mengembangkan kegiatan-kegiatan yang mendukung perkembangan pribadi siswa.

Siswa juga memberi pendapat mengenai metode yang digunakan selama proses pembelajaran ASG. Menurut pengakuan para siswa, secara keseluruhan metode yang digunakan mampu memotivasi setiap siswa untuk belajar berani menampilkan diri, mengungkapkan gagasan/pendapatnya di depan publik, dan 
mampu mempertanggungjawabkan hal-hal yang dipikirkannya. Selain itu, siswa juga didorong untuk bergaul dengan orang baru, mau bekerja sama, menghargai dan melayani sesama. Proyek pembuatan film dan foto esai merupakan metode yang membawa mereka terjun/melibatkan diri dalam persoalan-persoalan masyarakat di sekitar mereka. Pengalaman siswa terjun di tengah masyarakat dan mengalami kehidupan bersama sesama di sekitarnya bukan hanya berdampak bagi perkembangan diri sendiri, melainkan juga bagi orang lain yang dijumpai. Dengan proyek tersebut, para siswa lebih mudah mengingat nilai-nilai ASG yang dipelajari, dan terdorong untuk mensosialisasikan nilai-nilai tersebut kepada orang lain. Pada akhirnya metode pembelajaran ASG juga menantang siswa untuk mengubah kebiasaan, sikap dan perilaku dirinya dalam hidup sehari-hari bersama oang lain.

Secara keseluruhan, proses lokakarya mampu mengubah pandanganpandangan siswa antara lain mengenai: kehidupan masyarakat, Gereja, agama, Tuhan, keberadaan manusia, makna hidup, dan makna penderitaan. Pengaruh tersebut meneguhkan iman siswa, mendorong siswa untuk lebih terlibat dalam kehidupan Gereja. Selain itu, melalui lokakarya itu juga, siswa menemukan nilainilai yang perlu diperjuangkan dalam kehidupan, antara lain: belas kasih, solidaritas, empati, kepedulian, kepekaan, kejujuran, kekompakan, kerja sama, tanggung jawab, kedisiplinan, rasa syukur, dan homat kepada orang lain (termasuk yang berbeda dengan dirinya).

Proses dan hasil lokakarya ASG dipandang memiliki keterkaitan dengan Pendidikan Agama Katolik di sekolah, karena keduanya saling mendukung dan meneguhkan. Lokakarya ASG membantu siswa mengolah pengetahuan yang diperoleh di sekolah sehingga terasa lebih nyata bagi kehidupan sehari-hari. Sebaliknya, setiap kegiatan sosial masyarakat yang dilakukan siswa juga membutuhkan landasan pengetahuan iman yang memadai. Hal yang menarik adalah para siswa non Katolik ikut serta di dalam kegiatan sosial kemasyarakatan yang diadakan oleh para siswa Katolik dalam rangka lokakarya ASG. Catatan terakhir yang terungkap adalah: lokakarya dan kompetisi yang dilaksanakan Prodi belum cukup memadai dan sebaiknya tidak hanya dilakukan satu kali saja bila ingin meningkatkan ketertarikan para siswa pada ASG dan kepedulian mereka terhadap masalah-masalah sosial masyarakat. Para siswa dan guru pendamping yang turut serta dalam proses pembelajaran ASG berharap bahwa pembinaan berkelanjutan sangat dibutuhkan. Pihak sekolah diharapkan dapat menindaklanjuti upaya-upaya yang mampu menolong para siswanya dalam memahami ASG dan menumbuhkembangkan nilai-nilai ASG melalui berbagai cara dan terobosan yang baru. 


\subsection{Formasi OMK sebagai Agen Perubahan}

Berdasarkan keseluruhan proses dan hasil penelitian yang telah dilakukan di kalangan OMK, penulis memberikan gambaran mengenai isi, bentuk, dan proses pembelajaran ASG bagi OMK di dalam konteks hidup masyarakat, khususnya masyarakat megapolitan di jaman ini. Sejak awal persiapan lokakarya dan kompetisi, Prodi Pendikkat memang merencanakan sebuah proses pembelajaran kontekstual. Pembelajaran kontekstual "menghubungkan muatan akademis dengan konteks kehidupan sehari-hari siswa" sehingga "menghasilkan makna.” (Rusman, 2014:187.) Proses pembelajaran kontekstual ASG memberikan pengetahuan teoritis tentang dasar, sumber, dan isi ASG, serta pengalaman belajar terkait persoalan-persoalan terkini yang terjadi di lingkungan sekitarnya dengan mengajak para siswa SMA menyoroti persoalan-persoalan konkret sosialkemasyarakatan.

Metode eksposur, yang dinyatakan oleh para siswa sebagai metode yang menarik, merupakan bagian dari pembelajaran kontekstual. Wim Wentera menjelaskan demikian:

"The basic premise of contextual learning (or context-based learning) is that learning cannot take place in a vacuum, but should somehow be connected with real world attributes to make sense to learners. Such practical context allows learners to relate symbolic learning content like concepts and principles to their real world referents”. (Wentera, 2011: 202.)

Wentera mendukung pendapat Dan Hull bahwa para pembelajar mampu menghubungkan informasi yang diterimanya dengan kerangka dirinya. Kerangka personal digambarkan oleh Hull sebagai "their inner world of memory, experience, and response” yang terbentuk dari pengalaman-pengalaman individual dan interaksi-interaksinya dengan dunia nyata. Di dalam penelitian ini, si pembelajar adalah siswa peserta pelatihan, dan symbolic learning content-nya adalah konsepkonsep dan prinsip-prinsip ASG. Menggunakan rumusan Wentera dan Hull, peneliti merumuskan: para siswa memiliki kemampuan untuk menghubungkan berbagai konsep dan prinsip ASG dengan kerangka dirinya. Proses eksposur yang terjadi di dalam lokakarya ASG ikut membentuk kerangka diri para siswa yang terlibat di dalamnya. Di dalam proses itu, para siswa memperoleh sejumlah ingatan lewat pengalamannya melihat realitas sosial, dan memberikan respon terhadap realitas itu. Dengan demikian, pembelajaran konsep-konsep dan prinsipprinsip ASG menjadi hidup bagi mereka. Di situlah terlihat efektivitas metode pembelajaran ASG.

Efektivitas metode pembelajaran ASG juga dapat dilihat di dalam perubahan cara pandang dan pemikiran-pemikiran mereka yang terlibat di dalamnya. Hal ini sesuai dengan gagasan/teori konstruktivisme di dalam 
pendidikan, seperti yang diungkapkan oleh Fosnot (1989), yakni: "belajar bukan sekadar mengumpulkan fakta tetapi suatu proses yang berkembang dengan membuat kerangka pemikiran yang baru.”(Adisusilo, 2012: 180-181).)

Materi ASG sebenarnya merupakan materi kurikulum untuk siswa SMA kelas XI yang dibahas dalam pelajaran ke 16 sampai ke 18. Fakta di lapangan (sekolah) menunjukkan bahwa proses penyampaian materi kurikulum di sekolah pada umumnya bersifat penyampaian pengetahuan, sehingga proses pembelajaran ASG yang dilaksanakan melalui lokakarya ASG dipandang mampu membuat nilai-nilai ASG lebih mudah dipahami dan dirasakan dampaknya oleh siswa. Dengan demikian, apa yang dicita-citakan oleh Pendidikan Agama Katolik (PAK) di sekolah, seperti yang dimunculkan dalam kata pengantar buku PAK dan Budi Pekerti untuk SMA/SMK kurikulum 2013, dapat terwujud.

"Belajar bukan sekadar untuk tahu, melainkan dengan belajar seseorang menjadi tumbuh dan berubah....tidak [sekadar] belajar lalu berubah, tapi juga mengubah keadaan ... . Pembelajaran agama diharapkan dak hanya menambah wawasan keagamaan, tapi juga mengasah keterampilan beragama dan mewujudkan sikap beragama siswa. Sikap beragama yang utuh dan berimbang mencakup hubungan manusia dan penciptanya, dan hubungan manusia dengan sesama dan lingkungan sekitarnya.” (Boli Kotan \& P.Leo Sugiyono, 2014: iii).

Pernyataan tersebut menguatkan keyakinan penulis bahwa proses pembelajaran ASG bagi OMK dapat atau semestinya berfungsi sebagai formasi mereka sebagai agen-agen perubahan, yakni perubahan di dalam diri sendiri, keluarga, sekolah, Gereja, dan masyarakat. Fungsi formasi dapat berdampak apabila pembelajaran ASG bagi OMK dirancang dan dilaksanakan dengan memperhatikan hal-hal berikut:

1) proses pembelajaran ASG menerapkan prinsip-prinsip pembelajaran kontekstual yang bertolak dari situasi dan kebutuhan konkret orang muda, berciri partisipatif yang melibatkan pikiran, perasaan dan kehendak orang muda, reflektif yang terarah pada penemuan nilai-nilai dari pengalaman/keterlibatan, transformatif yang mampu menggerakkan OMK untuk membuat perubahan di dalam diri sendiri dan lingkungan sekitarnya, dan berkelanjutan sehingga menumbuhkan keinginan untuk terus menerus belajar dan bertumbuh-kembang ;

2) isi atau materi-materi yang disajikan di dalam proses pembelajaran ASG terkait dengan isu-isu konkret-aktual yang terjadi di sekitar orang muda; dalam hal ini, pengalaman dari keterlibatan di dalam kegiatan dan dari 
perjumpaan dengan masyarakat menjadi isi pembelajaran yang berharga, sama berharganya dengan doktrin-doktrin Gereja yang dipelajari;

3) bentuk pembelajaran ASG berkarakter peer group, melibatkan orang-orang muda di dalam kerja sama dengan sesama yang sebaya, melakukan sejumlah aktivitas yang memotivasi dan menantang mereka untuk mencari dan menemukan berbagai realitas sosial, keprihatinan yang ada di dalamnya, serta upaya yang dapat dilakukan untuk menanggapinya;

4) pelaksanaan pembelajaran ASG melibatkan orang-orang muda bukan Katolik dan tokoh-tokoh masyarakat yang dapat menjadi panutan bagi kaum muda; membuka peluang bagi OMK untuk membuat jejaring kerja sama lintas agama, lintas budaya, dan lintas generasi, yang terarah pada perjuangan mewujudkan nilai-nilai universal demi transformasi sosial masyarakat.

\section{PENUTUP}

Tulisan dan berbagai pernyataan lisan yang diungkapkan oleh Gereja menunjukkan adanya perhatian Gereja kepada OMK dan mengakui OMK sebagai harapan besar Gereja. Bersamaan dengan itu, Gereja juga mengemukakan keprihatinan-keprihatinan mengenai kualitas hidup OMK. Sekolah-sekolah Katolik, Bina Iman Anak dan Remaja, kelompok OMK di paroki-paroki, dan perayaan Youth Day (yang belakangan ini menjadi 'tradisi') menunjukkan kepedulian dan harapan Gereja kepada OMK. Hasil-hasil penelitian berkelanjutan yang dilakukan oleh Prodi Pendikkat Atma Jaya juga menunjukkan bahwa masih ada sejumlah keprihatinan yang terkait dengan kualitas berbagai kegiatan dan program pembinaan yang dilakukan Gereja untuk OMK. Dalam hal ini, institusi, kelompok, dan perayaan gerejawi bisa menjadi sekedar kesibukan dan kegiatan rutin Gereja apabila tidak mengandung pedagogi yang terencana, terarah, dan berkelanjutan, yang di dalam makalah ini penulis sebut sebagai: “formasi”. Wujud dari kepedulian dan harapan Gereja kepada OMK sendiri juga seharusnya bertransformasi.

Berbagai kegiatan dan program pembinaan bagi OMK yang dirancang dengan memperhatikan proses pedagogi yang terencana, terarah, dan berkelanjutan , seharusnya menjadi kompetensi lembaga-lembaga Pendikkat yang tergabung dalam Perkumpulan Pendidikan Keagamaan Katolik Indonesia (PERDIKKATI). Segala upaya untuk melakukan proses "formasi” bagi orang muda, membutuhkan komitmen, kesetiaan, dan keterbukaan untuk bekerja sama di antara sesama anggota PERDIKKATI, lembaga-lembaga pendidikan formal maupun informal dalam lingkup Gereja Katolik maupun dengan institusi lainnya yang ada di masyarakat. Pada akhirnya, kerja sama yang terutama harus dibangun 
adalah kerja sama dengan OMK dan orang-orang muda lainnya sebab merekalah agen-agen perubahan yang sesungguhnya dan seharusnya sudah berperan mulai saat ini dan bukan menunggu masa depan.

\section{DAFTAR PUSTAKA}

Adisusilo J.R., Sutarjo. 2012, Pembelajaran Nilai-Karater. Jakarta: Rajawali Pers. Boli Kotan, Daniel, 2014, Pendidikan Agama Katolik dan Budi Pekerti, Kelas XI, Jakarta: Pusat Kurikulum dan Perbukuan, Balitbang Kementerian Pendidikan dan Kebudayaan.

Cully, Iris V. 1995, Dinamika Pendidikan Kristen. Terj. Oleh P. Siahaan dan Stephen Suleeman. Jakarta: BPK Gunung Mulia.

Mesch, Gustavo S., 2009, “The Internet and Youth Culture.” dalam The Hedgehog Review. Spring , 50-60.

Petunjuk Umum Katekese, 2000, terj. Jakarta: Komkat dan Dokpen KWI.

Rusman, 2014, Model-Model Pembelajaran, Mengembangkan Profesionalisme Guru, Edisi Kedua. Jakarta: Rajawali Pers.

Setiawan, Ibnu.,2006, Penerjemah. Contextual Teaching and Learning, karya Elaine B. Johnson: Menjadikan Kegiatan Belajar-Mengajar Mengasyikkan dan Bermakna, Bandung: MLC.

Tjahaja, Liria.,2012, "Pemahaman Orang Muda Katolik Mengenai Sikap/Pandangan Gereja Terhadap Orang Miskin dan Masalah Kemiskinan (Studi Terhadap Kelompok Orang Muda Katolik di Keuskupan Agung Jakarta)," dalam Jurnal Pendidikan Agama Katolik (JPAK) Vol.8, Tahun ke-4, Oktober, hlm. 30-74. Madiun.

Wentera, Wim.,2011, “On the Changing Nature of Learning Context: Anticipating the Virtual Extensions of the World.” dalam Educational Technology \& Society, Vol.14 (2), 201-212.

Yap, Fu Lan.,2012 “Orang Muda Bicara tentang Pengaruh Komunikasi Berbasis Komputer terhadap Kehidupan Umat Beriman,” dalam Jurnal Teologi Vol. 01, Mei, hlm.51-56. Yogyakarta. 